\title{
Estimation of Bed Load Transport in River Osun, South-Western of Nigeria Using Grain Size Distribution Data
}

\section{Olaniyan, O.S., Adegbola, A.A., Adejumo, K.S. and Adeyokunu, A.T}

\begin{abstract}
Sediment transport rate depends on bed composition, flow hydraulics and sediment supply. There is a paucity of information on bedload transport in River Osun. In this study, bedload in River Osun was estimated using grain size distribution data to predict channel migration and mitigate flooding. Grab sampler was used to collect sediment samples at the sampling point across the river designated as $\mathrm{T}_{1}-\mathrm{T}_{4}$. Sieve analysis was carried out in triplicate on sediment from sampling points using standard methods. Discharge and cross-sectional area were measured between December 2017 and December 2018 at sampling stations using standard methods. The seasonal and bedload were estimated using standards equations. The percentage of bed material particles above $5 \mathrm{~mm}$ and less than or equal to $2 \mathrm{~mm}$ were 50 and $22.49 \%$, respectively. The average median grain $\left(\mathrm{d}_{50}\right)$ size was $2.4 \mathrm{~mm}$. The discharge and cross-sectional area across River Osun ranged $(0.53-17.46) \mathrm{m}^{3} / \mathrm{s}$ and $(3.83-47.46) \mathrm{m}^{2}$. The seasonal suspended and bedload across the river were $\left(206.43 \times 10^{3} \mathrm{~kg} / \mathrm{annum}\right)$ and $2,538.77 \times 10^{3}(\mathrm{~kg} /$ annum), respectively. The estimated sediment load of River Osun could be useful in determining the dredging period at any point across the river where deposition of sediment could be monitored.
\end{abstract}

Keywords: sediment, river osun, bedload, sieve analysis

\section{Introduction}

Sediment transport is one of the morphological studies that help in knowing seasonal changes that exist in rivers. In recent years, more attention has been given to sediment transport and river morphology studies due to environmental issues and the necessity to develop engineering and management strategies for the sustenance water use and hydraulic structure [1, 2]. Sediment transport rate depends on bed composition, flow hydraulics and upstream sediment supply. The deposition of the particle on the bed or when the particle is eroded can cause a change in the composition of the channel bed, which in turn changes flow hydraulics and fractional transport rates $[3,4]$.

River Osun is the largest river in Osun State,

Olaniyan, O.S., Adegbola, A.A, Adejumo, K.S. and
Adeyokunu, A.T (Department of Civil Engineering,
Ladoke Akintola University of Technology,
Ogbomoso, Nigeria)
Corresponding author: osolanivan@1autech.edu.ng
Telephone Number: +234-806-515-5439

the major tributaries of this river include Erinle River, Oba River and Omi Osun River. It was gauged where the tributaries were impounded for reservoir. For a scientific approach to different river problems, proper planning and design of water resources project, an understanding of the morphology and behaviour of the river is a prerequisite. Morphology (of river) is an aspect of science that has to do with the change of river plan form and cross-section due to sedimentation and erosion [4].

In the field, dynamics of flow and sediment transport are the principal element. The morphological studies, therefore, play a crucial role in planning, designing and maintaining river engineering structure. There has been a growing awareness about the need for making up a morphological study of river in the country, especially with particular reference to their unique problems $[2,5]$.

Either the balance between gravitational forces acting to settled particles on the bed of a stream or channel and the drag force that is 
acting to suspend the particle in the flow or along the direction of flow of the stream is one of the mechanisms of sediment transport [4]. Whenever shear stress exceeded a critical value, sediments are transported in form of bedload and suspended load [6, 2]. Different modes of sediment transport include wash load, dissolved load, suspended load siltation load and bedload. However, some of this mode cannot be separated in real practice [2].

\section{Materials and Method}

The data was collected on the river and it includes: discharge (Q) , water-surface width (B), flow depth $\left(\mathrm{Y}_{\mathrm{o}}\right)$, water-surface slope $\left(\mathrm{S}_{\mathrm{o}}\right)$, sediment load $\left(\mathrm{T}_{\mathrm{s}}\right)$, total load $\left(\mathrm{T}_{\mathrm{j}}\right)$, median sediment size $\left(\mathrm{d}_{50}\right)$, and Bedload (Tb). The data collected are in-line with similar study by [6]. The most important factor considered in selecting sampling point is safety during measurement. Also, unsteady bed condition and flow of water could affect the measurements, hence reach of the stable rivers were selected as measuring points. Gauging, velocity, bedload sample and suspended measurement were taken at four sampling stations $\left(\mathrm{T}_{1}-\mathrm{T}_{4}\right)$ across the river as shown in Figure 1. The material and equipment required for the field measurement and laboratory analysis includes:

(i) Filtering apparatus with $0.4 \mu \mathrm{m}$ filter paper to estimate suspended sediment concentration.

(ii) Ultrasonic current meter for measuring velocity at various depths.

(iii) Improvised depth integrated sampler and pump sediment sampler.

(iv) Ranging rods and meter rule for determining the slope of the river.

(v) Calibrated rope with concrete cube weight at its end to measure the depth of the river.

(vi) Turbidity meter for measuring the turbidity of the water. (vii) Analytical weighing balance for measuring suspended sediment concentration.

(viii) By sieves (stacked), wet sieves and other laboratory apparatus for grain size analysis.

A flow meter (model 32986-00) was used to measure the velocity at each cross-section of the river. The river channel was divided into sub-channels and the cross-sectional geometrical variables such as area, wetted perimeter, channels top width was computed for each sub channel. Integrated sampler was used to collect water samples used to determine Turbidity. The water samples were filtered and weigh to determine suspended sediment concentration. Grain size analysis was conducted on bedload sample in three trials using standard methods. Meyer-Peter, Einstein, Nielsen and Schoklitsch equations (equation 1-4) were compared in this study to determine bed load material while suspended sediment load was determined using equation established by United State Army Corps of Engineers as reported in [6]. Most of these bed load equations discussed are based on dimensionless shields parameter.

\section{A. Einstein Formula}

$$
\frac{u_{g}}{\sqrt{(s-1) g d_{g}^{z}}}=f\left(\frac{\rho l s-1) g d_{g}}{\tau_{o}}\right)
$$

Equation can be rewritten as:

$q_{s}=\sqrt{(s-1) g d_{a}^{3} f\left(\frac{g(s-1) g d_{g}}{\tau_{0}}\right)}$ 


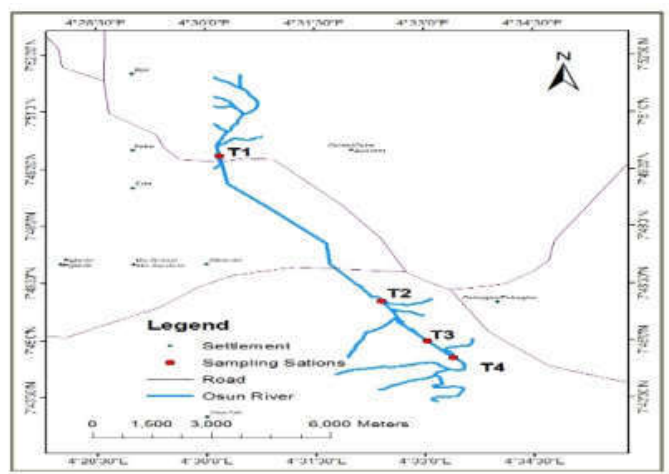

Figure 1: Map of the Study Area showing the Sampling Stations

where:

$f=0.202$,

$\tau_{. o}=$ egd $\sin \theta$,

$\mathrm{d}=$ water depth in $\mathrm{m}$,

$\mathrm{p}=$ density of water $\left(\mathrm{kg} / \mathrm{m}^{3}\right)$

$\mathrm{g}=$ acceleration due to gravity $\left(\mathrm{m} / \mathrm{s}^{2}\right)$

$\mathrm{q}_{\mathrm{s}}=$ volume rate of transport $\left(\mathrm{m}^{2} / \mathrm{s}\right)$

$\mathrm{d}_{\mathrm{s}}=\mathrm{d}_{50}$,

$\varrho_{\mathrm{s}}=$ sediment density $\left(\mathrm{kg} / \mathrm{m}^{3}\right)$,

$\mathrm{S}=\left(\varrho_{\mathrm{s}} / \varrho\right)=$ relative density.

$\sin \Theta=$ Channel slope

\section{B. Meyers Peter}

$$
\frac{a_{g}}{\sqrt{(s-1) g d_{g}^{2}}}=\left(\frac{4 x_{0}}{\rho(s-1) g d_{g}}-0.188\right)^{3 / 2}
$$

This equation is better simplified as:

$$
q_{s}=\left[\sqrt{(s-1)} g d_{s}^{3}\right] 8\left[\tau_{\pi}-\left(\tau_{*}\right)_{e}\right]^{3 / 2}
$$

where:

$$
\tau_{*}=\frac{R_{n} S}{(s-1) d_{s}},\left(\tau_{*}\right)_{c}=0.045
$$

$\mathrm{d}=$ water depth in $\mathrm{m}$,

$\mathrm{p}=$ density of water $\left(\mathrm{kg} / \mathrm{m}^{3}\right)$,

$\mathrm{g}=$ acceleration due to gravity $\left(\mathrm{m} / \mathrm{s}^{2}\right)$

$\mathrm{q}_{\mathrm{s}}=$ volume rate of transport $\left(\mathrm{m}^{2} / \mathrm{s}\right)$,

$\mathrm{d}_{\mathrm{s}}=\mathrm{d}_{50}, \varrho_{\mathrm{s}}=$ sediment density $\left(\mathrm{kg} / \mathrm{m}^{3}\right)$

$\mathrm{S}=\left(\varrho_{\mathrm{s}} / \varrho\right)=$ relative density,

$\sin \Theta=$ Channel slope

\section{Nielsen Equation}

$$
\begin{aligned}
& \frac{q_{g}}{\sqrt{(s-1) g d_{g}^{2}}}=\left(\frac{12 \tau_{g}}{\rho(s-1) g d_{g}}-0.05\right) \sqrt{\frac{\tau_{g}}{\rho(s-1) g d_{a}}} \\
& q_{s}=\sqrt{(s-1) g d^{n}}\left(\frac{12 \tau_{g}}{\rho(s-1) g d_{s}}-0.05\right) \sqrt{\frac{\tau_{m}}{\rho g-1 g d_{s}}}
\end{aligned}
$$

In Chanson (1999) the equation is modified to:

$$
\begin{aligned}
q_{s}=\mathrm{c}_{s} \frac{\delta_{g}}{d_{g}} \frac{v_{s}}{v_{m}} \\
\frac{s_{g}}{d_{s}}=2.5\left[\tau_{m}-\left(\tau_{\sharp}\right)_{s}\right] \\
\frac{v_{g}}{v_{s}}=4.8
\end{aligned}
$$

Equation 3(c) and 3(d) become:

$$
\begin{aligned}
& v_{s}=v_{\mathrm{t}} 4.8 \\
& \delta_{a}-d_{s} 2.5\left[\tau_{\pi}-\left(\tau_{\bar{*}}\right)_{c}\right.
\end{aligned}
$$

Where $\mathrm{c}_{\mathrm{s}}=0.65$

$v_{*}=\sqrt{g \mathrm{~d} \sin \theta}$

$\mathrm{d}=$ depth of water $(\mathrm{m})$

$\mathrm{g}=$ acceleration due to gravity $\left(\mathrm{m} / \mathrm{s}^{2}\right)$

$\tau_{\mp}=\frac{R_{R} s}{(s-1) d},\left(\tau_{\sharp}\right)_{o}=0.045$

$\mathrm{q}_{\mathrm{s}}=$ volumetric rate of sediment transport $\left(\mathrm{m}^{2} / \mathrm{s}\right)$

\section{Schoklitsch's Equation}

$$
m_{g}=2500(\sin \theta)^{3 / 2}\left(q-q_{e}\right)
$$

where:

$$
q_{0}=0.25(s-1)^{5 / 3} d_{50}^{3 / 2}(\sin \theta)^{-7 / 6}
$$

$\mathrm{ms}=$ mass sediment rate per unit width

$\mathrm{q}=$ volumetric water discharge $\left(\mathrm{m}^{3} / \mathrm{s}\right)$

$\mathrm{s}=$ relative density

$\sin \theta=$ bed slope

\section{Results and Discussion}

Bedload is the dominant load of unmeasured load. An appreciable quantity of unmeasured load across river Osun is recorded in-line with the study by [1]. About $95.22 \%$ of 
unmeasured load represents bed load across River Osun using limit particle size of $0.34 \mathrm{~mm}$. The bed load across River Osun can be classified as gravely particle and coarse sand particle with median grain size of 2.4 $\mathrm{mm}$. The gravely particle and coarse sand particle of the bed load is one of the factors that are responsible for the high-unmeasured load. The amount of sediment load estimated in Osun River could be useful to determine when Osun River would be dredged to prevent future flooding. The monthly unmeasured load across river Osun ranges between (38.36- 471.74) x10 ${ }^{3}$ (kg/month) while the monthly measured load across river Osun ranges between (106.74-1417.05 x10 $\mathrm{kg} /$ month). Equally, the seasonal unmeasured load across river Osun is $2477.17 \times 10^{3}$ $\mathrm{kg} /$ annum while the seasonal measured load across river Osun is $7035.54 \times 10^{3}$ (kg/annum). Tables $1-4$ show average monthly unmeasured load across River Osun.

Meyer Peter's equation is one of the wellknown and most used bedload sediment transport function. However, many researchers have shown that it is not applicable to all local Rivers. The study on fourteen (14) Rivers in Malaysia by [5] shows that Meyer Peter's and some other bed load functions over predicted bed load. Also, the study by [7] agreed that Schoklitsch's approach is more accurate than Meyer Peter method estimation. Meyer Peter and Muller (1948-1954) can be used for particle size between 0.4-2.85 $\mathrm{mm}$ while Schoklitsch's approach can be used for particles between 0.3-5 mm.

Meyer Peter's and simplified Nielsen's equations overestimated unmeasured load on River Osun because they were derived based on the laboratory experiments, which differs from such data on River Osun. Also, modified Einstein's equation does not respond directly proportionally to the geometrical data because it is an inverse of Shield's parameter though it does not overestimate. The unmeasured sediment load estimated using Schoklitsch's equation is within the range of load estimated in [7] simply because it is not only derived in the laboratory.

Table 1: Monthly Unmeasured Load using Schoklitsch's (1950) Equation

\begin{tabular}{llllll}
\hline $\begin{array}{l}\text { Stati } \\
\text { on }\end{array}$ & $\mathbf{Q}_{\mathbf{c}}$ & $\mathbf{Q}$ & $\mathbf{q}-\mathbf{q}_{\mathbf{c}}$ & $\mathbf{m}_{\mathbf{s}}$ & $\begin{array}{l}\mathbf{T}_{\mathbf{b}}(\mathbf{k g} / \mathbf{m o} \\
\mathbf{n t h})\end{array}$ \\
\hline $\mathrm{T}_{1}$ & 0.0556 & 0.121 & 0.0652 & 0.0210 & $54.43 \times 10^{3}$ \\
$\mathrm{~T}_{2}$ & 0.0406 & 0.265 & 0.224 & 0.152 & $241.98 \times 10^{3}$ \\
$\mathrm{~T}_{3}$ & 0.0365 & 0.48 & 0.443 & 0.284 & $736.13 \times 10^{3}$ \\
$\mathrm{~T}_{4}$ & 0.0541 & 0.0586 & 0.0045 & 0.00215 & $5.57 \times 10^{3}$ \\
\hline
\end{tabular}

Table 2: Monthly Unmeasured Load using Simplified Nelsien's (1992) Equation

\begin{tabular}{llllll}
\hline Station & $\mathbf{S}_{\mathbf{s}}$ & $\mathbf{V}_{\mathbf{s}}$ & $\mathbf{C}_{\mathbf{s}}$ & $\mathbf{Q}_{\mathbf{s}}$ & $\mathbf{T}_{\mathbf{b}}(\mathrm{kg} /$ month) \\
\hline $\mathrm{T}_{1}$ & 0.00382 & 0.775 & 0.65 & 0.00193 & $13,111.71 \times 10^{3}$ \\
$\mathrm{~T}_{2}$ & 0.00367 & 0.761 & 0.65 & 0.00182 & $12,364.44 \times 10^{3}$ \\
$\mathrm{~T}_{3}$ & 0.00368 & 0.762 & 0.65 & 0.00182 & $12,364.44 \times 10^{3}$ \\
$\mathrm{~T}_{4}$ & 0.00205 & 0.591 & 0.65 & 0.000788 & $5,350.04 \times 10^{3}$ \\
\hline
\end{tabular}

Table 3: Monthly Unmeasured Load using Simplified Meyer Peter's (1951) Equation

\begin{tabular}{|c|c|c|c|c|c|}
\hline $\begin{array}{l}\text { Stat } \\
\text { ion }\end{array}$ & $\mathbf{T}_{*}$ & $\begin{array}{l}\mathbf{T}_{*} \\
- \\
\mathbf{T} *_{\mathrm{c}}\end{array}$ & $\sqrt{ }\left(\mathrm{g}(s-1)\left(\mathrm{d}_{50}\right)^{3}\right.$ & $\mathbf{Q}_{\mathrm{s}}$ & $\begin{array}{l}\mathrm{T}_{\mathrm{b}}(\mathrm{Kg} / \\
\text { month) }\end{array}$ \\
\hline $\mathrm{T}_{1}$ & 0.684 & $\begin{array}{l}0.6 \\
37\end{array}$ & $4.687 \times 10^{-4}$ & $\begin{array}{l}1.906 \\
\times 10^{-3}\end{array}$ & $\begin{array}{l}12,948.66 \\
x 10^{3}\end{array}$ \\
\hline $\mathrm{T}_{2}$ & 0.659 & $\begin{array}{l}0.6 \\
12\end{array}$ & $4.687 \times 10^{-4}$ & $\begin{array}{l}1.975 \\
\times 10^{-3}\end{array}$ & $\begin{array}{l}13,417.42 \\
x 10^{6}\end{array}$ \\
\hline $\mathrm{T}_{3}$ & 0.661 & $\begin{array}{l}0.6 \\
14\end{array}$ & $4.687 \times 10^{-4}$ & $\begin{array}{l}1.806 \\
\times 10^{-3}\end{array}$ & $\begin{array}{l}12,269.30 \\
x 10^{3}\end{array}$ \\
\hline $\mathrm{T}_{4}$ & 0.398 & $\begin{array}{l}0.3 \\
51\end{array}$ & $4.687 \times 10^{-4}$ & $\begin{array}{l}7.780 \\
\times 10^{-4}\end{array}$ & $\begin{array}{l}5,285.45 x \\
10^{3}\end{array}$ \\
\hline
\end{tabular}

Table 4: Monthly Unmeasured Load using Modified Enstein's (1950) Equation

\begin{tabular}{|c|c|c|c|c|}
\hline $\begin{array}{l}\text { Stat } \\
\text { ion }\end{array}$ & $f\left(\frac{g q-1 g g n}{T_{g}}\right.$ & $\sqrt{\left.g(s-1) u_{E Q}\right)}$ & $\mathbf{Q}_{\mathrm{s}}$ & $\begin{array}{l}\mathrm{T}_{\mathrm{b}}(\mathrm{Kg} / \\
\text { month })\end{array}$ \\
\hline $\mathrm{T}_{1}$ & 0.295 & $4.687 \times 10^{-4}$ & $\begin{array}{l}1.384 \times 10^{-} \\
4\end{array}$ & $\begin{array}{l}0.937 \times 10 \\
3\end{array}$ \\
\hline $\mathrm{T}_{2}$ & 0.307 & $4.687 \times 10^{-4}$ & $\begin{array}{l}1.439 \times 10^{-} \\
4\end{array}$ & $\begin{array}{l}0.977 \times 10 \\
3\end{array}$ \\
\hline $\mathrm{T}_{3}$ & 0.306 & $4.687 \times 10^{-4}$ & $\begin{array}{l}1.432 \times 10^{-} \\
4\end{array}$ & $\begin{array}{l}0.973 \times 10 \\
3\end{array}$ \\
\hline $\mathrm{T}_{4}$ & 0.508 & $4.687 \times 10^{-4}$ & $\begin{array}{l}2.3791 \times 1 \\
0^{-4}\end{array}$ & $\begin{array}{l}1.616 \times 10 \\
3\end{array}$ \\
\hline
\end{tabular}

However, the sieve analyses of the sediment at sampling point $T_{1}-T_{4}$ are presented in Tables 5-8. Average grain size distribution of bed material across River Osun is presented in 
Figure 2. The effective mean sediment size was $2.4 \mathrm{~mm}$.

Table 5: Particle Size Analysis of Bed Material on River Osun at Sampling Station $\mathrm{T}_{1}$

\begin{tabular}{lll}
\hline Sieve size $\mathbf{( m m )}$ & \% retained & \% distribution \\
\hline 8 & 100 & 24.1 \\
4 & 75.95 & 19.03 \\
2 & 56.92 & 31.72 \\
1 & 25.20 & 15.73 \\
0.425 & 9.47 & 4.73 \\
0.25 & 4.98 & 2.65 \\
0.125 & 2.33 & 1.7 \\
0.75 & 0.63 & 0.3 \\
& 0.33 & 0.6 \\
\hline
\end{tabular}

Table 6: Particle Size Analysis of Bed Material on River Osun at Sampling Station $\mathrm{T}_{2}$

\begin{tabular}{lll}
\hline Sieve size $\mathbf{( m m})$ & \% retained & \% distribution \\
\hline 8 & 100 & 49.29 \\
4 & 50.71 & 10.27 \\
2 & 40.44 & 10.67 \\
1 & 29.77 & 8.81 \\
0.425 & 20.96 & 14.61 \\
0.25 & 6.35 & 4.83 \\
0.125 & 1.52 & 1.28 \\
0.75 & 0.24 & 0.16 \\
& 0.08 & 0.08 \\
\hline
\end{tabular}

Table 7: Particle Size Analysis of Bed Material on River Osun at Sampling Station $\mathrm{T}_{3}$

\begin{tabular}{lll}
\hline Sieve size $\mathbf{( m m})$ & \% retained & \% distribution \\
\hline 8 & 100 & 24.71 \\
4 & 75.29 & 29.9 \\
2 & 43.39 & 28.39 \\
1 & 17.00 & 11.81 \\
0.425 & 5.19 & 2.55 \\
0.25 & 2.64 & 0.95 \\
0.125 & 1.69 & 1.05 \\
0.75 & 0.64 & 0.28 \\
& 0.36 & 0.26 \\
\hline
\end{tabular}

Table 8: Particle Size Analysis of Bed Material on River Osun at Sampling Station $\mathrm{T}_{4}$

\begin{tabular}{lll}
\hline Sieve Size $\mathbf{( m m )}$ & \% retained & \% distribution \\
\hline 8 & 100 & 43.07 \\
4 & 56.93 & 15.7 \\
2 & 41.23 & 18.65 \\
1 & 22.58 & 11.74 \\
0.425 & 10.84 & 5.32 \\
0.25 & 5.52 & 1.59 \\
0.125 & 1.9 & 0.19 \\
0.75 & 0.33 & 0.19 \\
& 0.14 & 0.12 \\
\hline
\end{tabular}

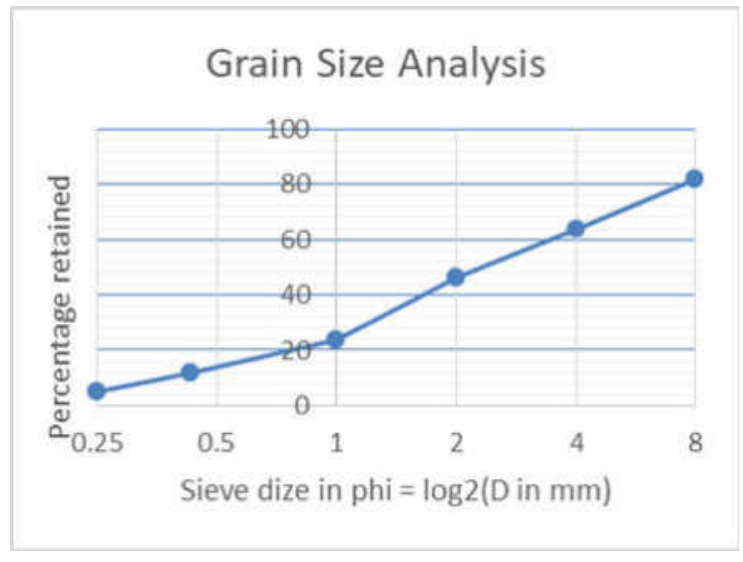

Figure 2: Average Grain Size Distribution Curve of Bed Material across River Osun

\section{Conclusion}

The following conclusions were drawn from this study

i. The bed load material of River Osun has a mean particle size of $2.4 \mathrm{~mm}$.

ii. Meyer Peter's equation and Nelson equations overestimated the unmeasured load on River Osun as a result of the lower percentage of slope used in its derivation.

iii. Meyer Peter's and Nielson's equations estimation of sediment loads were closer in values while Eisten's equation result differs.

\section{Recommendation from the Study}

This recommendation was made from this study

Meyer-Peter's and Nielsen equation gave a reasonable result while Einstein equation (1950) result is not close to these two. Therefore Meyer-Peter's equation and Nielsen equation are recommended for particles size of bedload above $5 \mathrm{~mm}$ and for rivers with low bed slope.

\section{Acknowledgement}

The authors acknowledge Tertiary Education Trust Fund (TETFund) and Authorities of 
Ladoke Akintola University of Technology, Ogbomoso for the Institution Based Research (IBR) grant (PV No: 00082805) to carry out this research.

\section{References}

[1] Adegbola, A.A. and Olaniyan O.S. "Temporal variation of Sediment Transport in River-Omi, South-Western Nigeria", International Journal of Applied Engineering Research, vol. 4, no. 7, 2012, pp 421-431.

[2] Yang, C.T. "Sediment Transport, Theory and Practice", McGraw-Hill, New York, 1996.

[3] Olaniyan, O.S. and Adegbola, A.A. "Comparison of Sediment Transport Models on River Omi, South-Western Nigeria", Biodiversity International Journal, vol. 2, no. 1, 2018, pp 66-73

[4] Otun, J.A. and Adeogun, B.K. "Analysis of Fluvial Sediment Discharge into Kubanni Reservoir", Nigeria Journal of Technology, vol. 29, no. 2, 2010, pp 67-69.

[5] Kiat, C.H., Ghani, A.A. and Wen, L.M. "Development of Modified Einstein Bed Load Equation for Sandy stream in Malaysia", 2nd International Conference on Managing Rivers in the 21, Century. Riverside Kuching, Sarawak, Malaysia, August 3-6, 2007, pp. 533-538.

[6] Olaniyan O.S. "Numerical Modelling of Sediment Transport in River Omi, South-Western Nigeria", Unpublished Ph.D Thesis, Civil Engineering Department, Ladoke Akintola University of Technology, Ogbomoso, Nigeria, 2014.

[7] Bishaw, D. and Kedir, Y. (2015). "Determining sediment Load of Awash River Meteharra Sugarcane Irrigation Scheme in Ethiopia". Journal of Environment and Earth Science, vol.5, no. 13: pp 110-117 